\title{
Effect of aerial part and root extracts from Ferulago mughlae Peșmen and Ferulago sandrasica Peșmen \& Quézel growing in Turkey on erectile dysfunction in streptozotocin-induced diabetic rats
}

\author{
Songül KARAKAYA ${ }^{1}$ * (D) , Fatmagül DELIMUSTAFAOĞLU-BOSTANLIK ${ }^{2}$ (D), \\ Didem YILMAZ-ORAL ${ }^{3,4} \mathbb{D}$, Serap GÜR ${ }^{4}$ (D) , Ceyda Sibel KILIÇ ${ }^{2}$ (D)
}

1 Department of Pharmacognosy, Faculty of Pharmacy, Ataturk University, Erzurum, Turkey.

2 Department of Pharmaceutical Botany, Faculty of Pharmacy, Ankara University, Ankara, Turkey.

3 Department of Pharmacology, Faculty of Pharmacy, Çukurova University, Adana, Turkey.

4 Department of Pharmacology, Faculty of Pharmacy, Ankara University, Ankara, Turkey

* Corresponding Author. E-mail: songul.karakaya@atauni.edu.tr (S.K.) ; Tel. +904422315250.

Received: 27 March 2018 / Revised: 09 August 2018/ Accepted: 14 August 2018

\begin{abstract}
Ferulago species have been utilised since ancient times as antihelmentic, peptic, sedative and aphrodisiac, and as the seasoning in view of their special odors. In Turkish traditional medicine, the roots from some members of this genus are utilized as aphrodisiac, so we determined to show in vitro relaxant effect of F. mughlae Peșmen and F. sandrasica Peșmen \& Quézel species extracts on corpus cavernosum (CC). A totality of 20 adult male Sprague-Dawley rats (diabetic and control groups) were induced by single intraperitoneal injection of $40 \mathrm{mg} / \mathrm{kg}$ of Streptozotocin. In vitro organ bath tests were carried out on rats to evaluate isometric pressure. Tissues were stretched with phenylephrine (Phe), and relaxation responses relevant to acetylcholine (ACh, $1 \mathrm{mM}$ ), sodium nitroprusside (SNP $0.1 \mu \mathrm{M})$ and electrical field stimulation (EFS, frequency $20 \mathrm{~Hz}$ ) were gained. Whole these concentration-response curves were replicated with aqueous extracts obtained from the aerial parts and roots. The extracts were active in both groups. It was found that root extracts of F. mughlae and F. sandrasica yielded $97.80 \%$ and $97.55 \%$ relaxation. Among the extracts of roots (especially roots of F. mughlae) showed the best activity. On the other hand, lyophilized aqueous extracts of aerial part (especially F. sandrasica) showed the worst activity. Based on this findings, the roots of this species deserve further in vivo assessments for their aphrodisiac potential.
\end{abstract}

KEYWORDS: Aphrodisiacs; Apiaceae; Ferulago; erectile function.

\section{INTRODUCTION}

Diabetes is one of the most prevalent causes of erectile dysfunction (ED), which eminently influences the standard of living and the risk of developing ED in diabetic men is threefold higher than in healthy men $[1,2]$. As compared with the other complications of diabetes, the development of ED begins at an earlier age. Moreover, the incidence and intenseness of ED increase with during of diabetes [3], and multifactorial mechanisms including neurogenic and vasculogenic factors are involved in diabetic ED. The efficacy of some ED treatments is limited for diabetes-associated ED. For example, men with diabetes frequently represent a weak response to first-line oral phosphodiesterase type 5 (PDE-5) inhibitors [4]. Alternative therapy choice may be phytotherapy for diabetic ED.

In this investigation, we purposed to indicate the effect of the lyophilized aqueous extracts of Ferulago species growing naturally in Turkey on the erectile tissue. In Turkey these species are known as "Çağşır" or "Çakşır" and utilized conventionally as aphrodisiac in Southeast and South Anatolia [5]. Actually, plenty members of Ferulago, Prangos and Ferula genus have been utilized on this aim. These species are utilized in rutting of goat and sheep, besides the aqueous decoctions of the roots and aerial parts are used internally as aphrodisiacs [5]. Apart from medical utilization, aerial part of some Ferulago species have been eaten as salad or seasoning based upon their special odour, otherwise as nourishment for goats and deer [5].

\footnotetext{
How to cite this article: Karakaya S, Delimustafaoglu-Bostanlık F, Yılmaz-Oral D, Gur S, Kılıc CS. Effect of Aerial part and Root Extracts from Ferulago mughlae Peșmen and Ferulago sandrasica Peșmen \& Quézel Growing in Turkey on Erectile Dysfunction in Streptozotocin-Induced Diabetic Rats. J Res Pharm. 2019; 23 (2): 235-241.
} 
Ferulago W. Koch. (Apiaceae) is presented 34 taxa in Turkey 19 of that are endemic [6]. F. mughlae Peșmen and F. sandrasica Peșmen \& Quézel (Apiaceae) are glaucous, perennial, glabrous species, growing in Marmaris and Sandras Mountain, Mugla, West Anatolia, Turkey, respectively [7]. During our studies, we have found that extracts from aerial parts and roots of Ferulago species established relaxation in precontracted rat corpus cavernosum. Thereby, we attributed to search pharmacological side view of their relaxant effect by utilizing isolated corpus cavernosum tissue in vitro. This investigation purposes to give an initial report to evaluate the effect of extracts from F. mughlae and F. sandrasica on ED in streptozotocin (STZ)-induced diabetic rats.

\section{RESULTS}

\subsection{Extraction}

These species are utilized in rutting of goat and sheep, besides the aqueous decoctions of the roots and aerial parts are utilized internally as aphrodisiacs [5]. So, lyophilized aqueous extracts from the aerial parts and roots of Ferulago species were evaluated for their effect on erectile dysfunction.

\subsection{Characteristics of Animals}

Body weight in diabetic rats was considerably lower than in control rats (Figure 1A, P<0.001). Blood glucose levels in the diabetic group were considerably higher than in the control group (Figure $1 \mathrm{~B}, \mathrm{P}<0.001$ ).

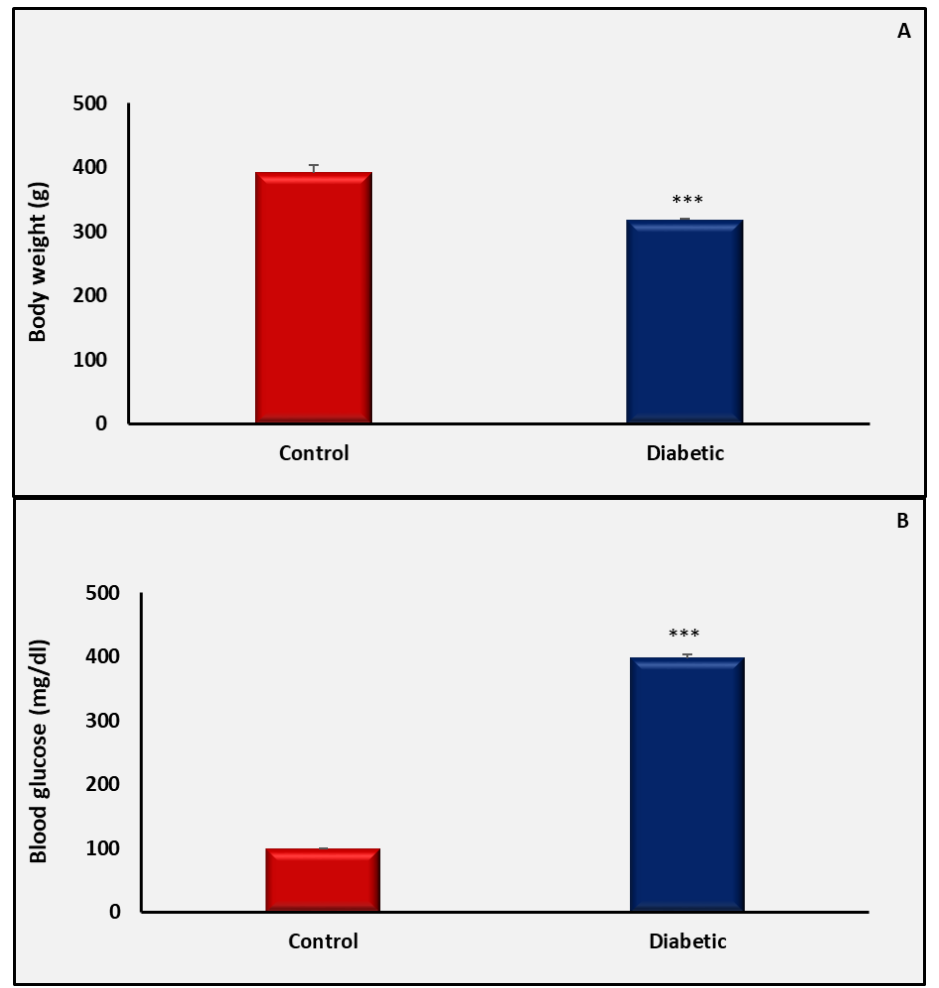

Figure 1. Bar graph showing body weight of control and diabetic groups (A) and glucose levels (B) in control and diabetic groups. Data are mean $\pm \operatorname{SEM}(n=6)$ and ${ }^{* * *} \mathrm{p}<0.001$ vs control.

\subsection{In vitro Responses of CC Strips}

Among the extracts root extract of Ferulago mughlae showed best relaxation against Phe $(97.80 \% \pm 1.98)$. On the other hand, aerial part extract of $F$. sandrasica had the worst relaxation against Phe $(57.02 \% \pm 1.56)$.

The endothelial-dependent relaxation response to ACh $(1 \mathrm{mM})$ in control rats was higher than in diabetic rats, which was enhanced afterwards the incubation of the extracts $(100 \mu \mathrm{M})$ in diabetic and control groups (Table 1). 
Table 1. Relaxation responses of corpus cavernosum tissues taken from control and diabetes groups of species.

\begin{tabular}{|c|c|c|c|c|c|c|c|}
\hline \multirow[t]{2}{*}{ Species } & & \multicolumn{2}{|c|}{ Acetylcholine } & \multicolumn{2}{|c|}{ EFS } & \multicolumn{2}{|c|}{ SNP } \\
\hline & & Control & Diabetic & Control & Diabetic & Control & Diabetic \\
\hline \multirow[t]{2}{*}{ F. mughlae } & AR & $\begin{array}{l}73.567 \\
\pm 0.987\end{array}$ & $\begin{array}{l}33.387 \\
\pm 0.877\end{array}$ & $\begin{array}{l}53.355 \\
\pm 0.459\end{array}$ & $\begin{array}{l}19.645 \\
\pm 0.566\end{array}$ & $\begin{array}{r}91.238 \\
\pm 0.588\end{array}$ & $\begin{array}{l}88.335 \\
\pm 0.588\end{array}$ \\
\hline & $\mathrm{AH}$ & $\begin{array}{l}60.451 \\
\pm 0.477\end{array}$ & $\begin{array}{l}28.598 \\
\pm 1.099\end{array}$ & $\begin{array}{r}48.690 \\
\pm 2.012\end{array}$ & $\begin{array}{l}11.566 \\
\pm 0.702\end{array}$ & $\begin{array}{r}89.866 \\
\pm 0.366\end{array}$ & $\begin{array}{l}85.558 \\
\pm 0.377\end{array}$ \\
\hline \multirow[t]{2}{*}{ F. sandrasica } & $\mathrm{AR}$ & $\begin{array}{l}68.692 \\
\pm 1.213\end{array}$ & $\begin{array}{l}34.387 \\
\pm 0.455\end{array}$ & $\begin{array}{l}52.586 \\
\pm 0.366\end{array}$ & $\begin{array}{l}19.543 \\
\pm 0.703\end{array}$ & $\begin{array}{r}91.656 \\
\pm 0.489\end{array}$ & $\begin{array}{l}90.787 \\
\pm 0.681\end{array}$ \\
\hline & $\mathrm{AH}$ & $\begin{array}{l}58.678 \\
\pm 0.239\end{array}$ & $\begin{array}{l}30.889 \\
\pm 0.671\end{array}$ & $\begin{array}{l}48.856 \\
\pm 0.834\end{array}$ & $\begin{array}{l}10.456 \\
\pm 0.811\end{array}$ & $\begin{array}{r}91.650 \\
\pm 0.590\end{array}$ & $\begin{array}{l}84.005 \\
\pm 1.027\end{array}$ \\
\hline
\end{tabular}

AR: Aqueous extract of root, AH: aqueous extract of aerial part.

EFS-induced relaxation response at $20 \mathrm{~Hz}$ was reduced in the diabetic group contrasted with the control group, which was restored by the incubation with the extracts $(100 \mu \mathrm{M})$. There was no distinctness in EFSinduced relaxation response in control rats among the presence and absence of the extracts (Table 1).

SNP- induced endothelial-independent relaxation response at $0.1 \mu \mathrm{M}$ dosage relaxation was not changed in control rats when contrasted with diabetic rats (Table 1). Though, relaxation responses to SNP were enhanced in the presence of the extracts $(100 \mu \mathrm{M})$ in diabetic and control rats.

Among the extracts the best acetylcholine relaxation responses were shown at root extract of $F$. mughlae in control group $(73.567 \%)$, root extract of $F$. sandrasica in diabetic group (19.645\%), on the other hand, the worst activity was seen at aerial part extract of $F$. sandrasica in control group (58.678\%), root extract of $F$. mughlae in diabetic group (28.598\%).

Among the extracts the best EFS relaxation responses were shown at root extract of F. mughlae $(53.355 \%$, $19.645 \%$ control and diabetic groups, respectively), on the other hand, the worst activity was seen at aerial part extract of F. mughlae (48.690\%, 10.456\% control and diabetic groups, respectively).

Among the extracts the best SNP relaxation responses were shown at root extract of F. sandrasica (91.656\%, 90.787\% control and diabetic groups, respectively), on the other hand, the worst activity was seen at aerial part extract of $F$. mughlae $(89.866 \%, 85.558 \%$ control and diabetic groups, respectively). The findings are shown in Table 1.

\section{DISCUSSION}

In this investigation, we purposed to perform the relaxant effect of lyophilized aqueous extracts of aerial parts and roots from Ferulago mughlae and F. sandrasica in corpus cavernosum with in vitro studies. Corporal smooth muscle relaxation shows a significant role in erection. Smooth muscle relaxation mixed with nitric oxide (NO) during sexual stimulation is synthesized by nerve terminals of the penile parasympathetic noncholinergic and non-adrenal nerves, besides endothelial cells covering the blood vessels of the corpus cavernosum and lacunar gaps [9]. Penile erection in response to $\mathrm{CN}$ stimulation was made firm in a diabetic animal model. Our findings demonstrated that diabetes decreased the in vitro relaxant response of CC to EFS. In in vitro investigations, the nitrergic relaxation response to EFS in diabetic rats was increased by the incubation of extracts. There are no recent findings to assess the effect of these species on erectile function. Though, the extracts reduced in the diabetes-induced renal damage related to the diabetic nephropathy [10]. Moreover, the extracts improved the effects of non-enzymatic and enzymatic antioxidants [11], also in vitro augmented the glycolytic activities [12]. These results propose a rationale for more studies utilizing combinations of the extracts and PDE-5 inhibitors in diabetes-induced ED.

The recent investigation indicated that extract-induced relaxation in CC of the diabetic group was not changed when contrasted with CC from the control group. It seems that the extracts responses serve as the normal activity in vitro under diabetic provisions. 
In the isolated CC from the diabetic group, endothelium-dependent relaxation response to ACh was considerably decreased that was potentialized in the existence of the extracts. There are no heretofore supporting findings like to these data.

There was not the difference between the endothelial-independent relaxation response to SNP in control and diabetic rats, which was enhanced in groups afterward the incubation of extracts. In recent researches, SNP-induced relaxant responses did not change in diabetic rats while contrasted with controls $[13,14]$.

As shown in Figure 2-5 among the extracts of roots (especially roots of F. mughlae) showed the best activity. On the other hand, lyophilized aqueous extracts of aerial part (especially F. sandrasica) showed the worst activity.

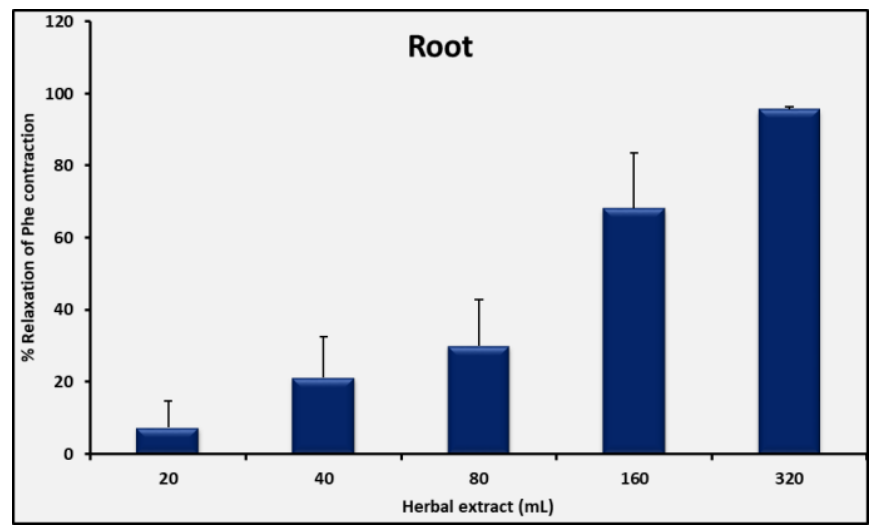

Figure 2. Effects of aqueous extract of root from F. mughlea $(100 \mu \mathrm{M})$ on rats corporal relaxation by in rats corpus cavernosum precontracted with phenylephrine. Data are shown as mean \pm S.E.M for three preparations at diabetic group.

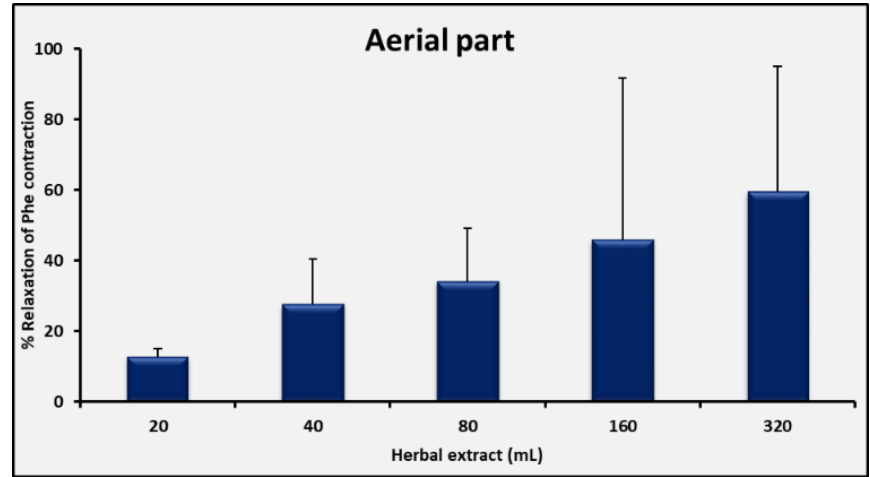

Figure 3. Effects of aqueous extract of aerial part from F. mughlea $(100 \mu \mathrm{M})$ on rats corporal relaxation by in rats corpus cavernosum precontracted with phenylephrine. Data are shown as mean \pm S.E.M for three preparations at diabetic group.

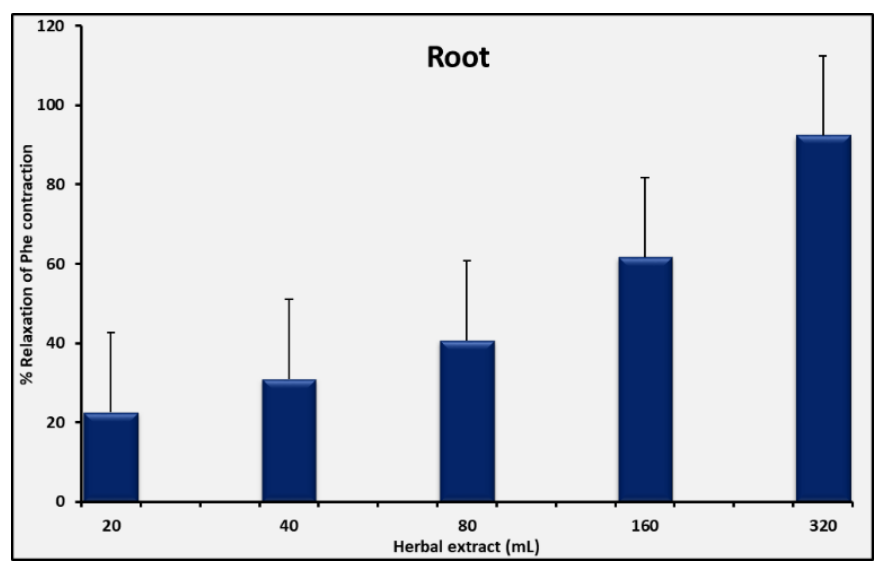


Figure 4. Effects of aqueous extract root of from F. sandrasica $(100 \mu \mathrm{M})$ on rats corporal relaxation by in rats corpus cavernosum precontracted with phenylephrine. Data are shown as mean \pm S.E.M for three preparations at diabetic group.

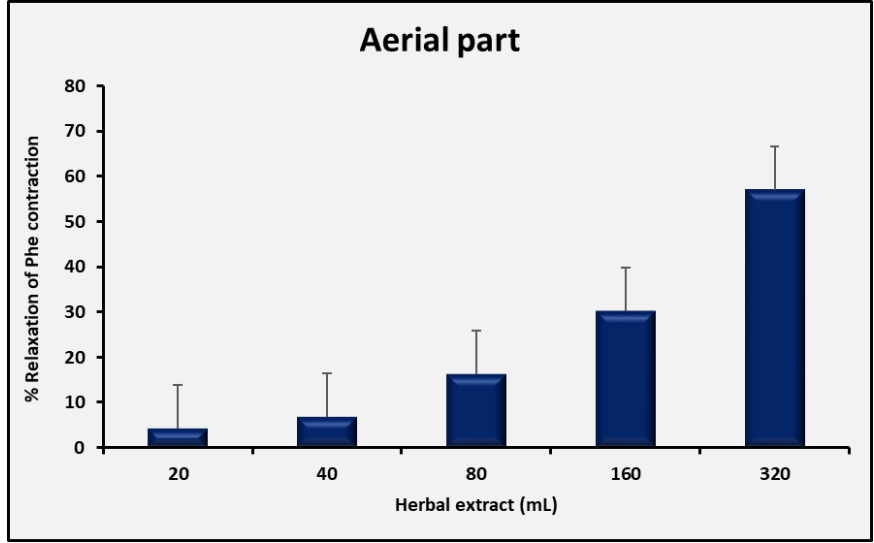

Figure 5. Effects of aqueous extract aerial part of from $F$. sandrasica $(100 \mu \mathrm{M})$ on rats corporal relaxation by in rats corpus cavernosum precontracted with phenylephrine. Data are shown as mean \pm S.E.M for three preparations at diabetic group.

\section{CONCLUSION}

Therefore we can conclude that these species (especially the roots) can be used in erectile dysfunction and may represent a herbal alternative to synthetic drugs.

\section{MATERIALS AND METHODS}

\subsection{Plant material}

Ferulago mughlae and F. sandrasica were collected in 2013 from Marmaris and Sandras Mountain, Muğla, Turkey, respectively by Fatmagül Delimustafaoglu Bostanlik and they were identified by a plant taxonomist (Prof. Dr. Hayri Duman, at the Department of Biology, Faculty of Science, Gazi University). The voucher samples are conserved at the Herbarium of Ankara University, Faculty of Pharmacy (AEF 26356 and 26274, respectively).

\subsection{Extraction}

$50 \mathrm{~g}$ of aerial parts and roots from these plants were powdered and macerated with $200 \mathrm{~mL}$ of distilled water for $8 \mathrm{~h} / 3$ days at 25 to $30^{\circ} \mathrm{C}$, separately. The aqueous extract was filtered, freezed (Sanyo Medical Freezer, Germany) and lyophilized (Christ ${ }^{\circledR}$ Gamma 2-16 LSC, Germany) to give aqueous extracts from roots and aerial parts. Roots and aerial parts of Ferulago mughlae and F. sandrasica gave 3.24, 2.45, 3.98 and $2.78 \mathrm{~g}$ extracts, respectively.

\subsection{Animals}

Twenty male Sprague-Dawley rats weighing 300 to $350 \mathrm{~g}$ were randomly divided into control (10) and diabetic (10) groups, which were given a dosage of streptozotocin (STZ, $40 \mathrm{mg} / \mathrm{kg}$, i.p.) within a citrate buffer $(\mathrm{pH}=5.5)$ at the day of usage [8]. Seventy-two hours after STZ injection, blood glucose levels were measured using a blood glucose meter (Accu-Chek, Roche, Mannheim, Germany). The animals were housed in apart cages on a 12-h light-dark cycle and were fed standard water and chow ad libitum. This investigation was confirmed by the Institutional Animal Care and Use Committee of Ankara University (2014-15-86).

\subsection{Isometric Tension Measurings}

CC strips were installed at organ bath chambers and serviced in Krebs-bicarbonate solution (continuing, mM: $\mathrm{MgSO}_{4} ; 1.0, \mathrm{NaHCO}_{3} ; 25.0, \mathrm{KCl} ; 4.7, \mathrm{NaCl} ; 118.1, \mathrm{KH}_{2} \mathrm{PO}_{4} ; 1.0$, glucose; 11.1 and $\mathrm{CaCl} ; 22.5$, pH:7.4). The strips $\left(1 \times 1 \times 9 \mathrm{~mm}^{3}\right)$ were dissected and combined under $1 \mathrm{~g}$ of endurance tension in a 20-ml organ bath. The organ chamber temperature was kept going at $37^{\circ} \mathrm{C}$ via a circulating water bath and enduring bubbling with a commixture of $95 \% \mathrm{O}_{2}, 5 \% \mathrm{CO}_{2}$. The tissues were permitted to equalize for a minimum of $60 \mathrm{~min}$, and the bath solution was changed place each $15 \mathrm{~min}$. EFS of the autonomic nerves (duration: $15 \mathrm{sec}$; amplitude: 50-90 
V; frequency: pulse width: $5 \mathrm{~ms}$ ) was consummated as a means of platinum electrodes, emplaced on the couple side of the tissue strip (Grass Instruments, Quincy, MA).

In the initial series of assays, CC strips were precontracted with Phe $\left(10^{-5} \mathrm{M}\right)$ and permitted to relax afterward administration of the extracts.

In the secondary series of trials, acetylcholine (ACh), EFS and sodium nitroprusside (SNP)induced relaxation responses were stimulated afterward precontraction of CC strips with Phe $\left(10^{-5} \mathrm{M}\right)$ in the existence or absence of extracts $(100 \mu \mathrm{M})$.

\subsection{Statistical Analysis}

Whole findings are expressed as mean \pm SE and variation among means were statistically analyzed utilizing One-way analysis of ANOVA followed by Bonferroni's complementary analysis, with $\mathrm{P}<0.05$ considered to demonstrate statistical significance. In the end the study, each CC strips were measured. Whole contractile responses were stated as $\mathrm{mg}$ of tension improved per $\mathrm{mg}$ of corporal tissue and relaxant responses were calculated as a percentile of Phe-contraction.

\subsection{Drugs}

Whole drugs were bought from Sigma Chemical Co (St. Luis, MO).

Acknowledgement: Authors thank Prof. Dr. Hayri Duman for his worthwhile backing for identifying of plant material.

Author contributions: Concept - S.K., D.Y.O.; Design - S.K., D.Y.O.; Supervision - C.S.K., S.G.; Resource -S.K., F.D.B.; Materials - S.K., F.D.B., D.Y.O.; Data Collection and/or Processing - S.K., F.D.B., D.Y.O.; Analysis and/or Interpretation - S.K., D.Y.O., S.G.; Literature Search - S.K., D.Y.O.; Writing - S.K., D.Y.O.; Critical Reviews - S.K., F.D.B., D.Y.O., S.G., C.S.K.

Conflict of interest statement: The authors enounce that they have no conflict of interest.

\section{REFERENCES}

[1] Mazzilli R, Elia J, Delfino M, Benedetti F, Scordovillo G, Mazzilli F. Prevalence of diabetes mellitus (DM) in a population of men affected by erectile dysfunction (ED). Clin Ter. 2015; 166(5): 317-320. [CrossRef]

[2] Rastrelli G, Corona G, Mannucci E, Maggi M. Vascular and chronological age in subjects with erectile dysfunction: a cross-sectional study. J Sex Med. 2015; 12(12): 2303-2312. [CrossRef]

[3] Johannes CB, Araujo AB, Feldman HA, Derby CA, Kleinman KP, Mckınlay JB. Incidence of erectile dysfunction in men 40 to 69 years old: longitudinal results from the Massachusetts male aging study. J Urol. 2000; 163(2): 460-463. [CrossRef]

[4] Ruan Y, Li M, Wang T, Yang J, Rao K, Wang S, Yang W, Liu J, Ye Z. Taurine supplementation improves erectile function in rats with streptozotocin-induced type 1 diabetes via amelioration of penile fibrosis and endothelial dysfunction. J Sex Med. 2016; 13(5): 778-785. [CrossRef]

[5] Erdurak CS. PhD Thesis. Investigations on Ferulago isaurica Peşmen and F. syriaca Boiss. (Umbelliferae) species. Department of Pharmaceutical Botany, Faculty of Pharmacy, Ankara University, Tandogan, Ankara, Turkey, 2003. [CrossRef]

[6] Güner A, Türkiye Bitkileri Listesi (Damarlı Bitkiler), Flora Dizisi 1, first ed., İstanbul Nezahat Gökyiğit Botanik Bahçesi Publ., Istanbul, Turkey 2012.

[7] Peşmen H. Ferulago W. Koch. In: Davis PH. (Ed). Flora of Turkey and the East Aegean Islands. Edinburgh University Press, Edinburgh, 1972, pp. 469.

[8] Yilmaz OD, Bayatli N, Gur S. The beneficial effect of fesoterodine, a competitive muscarinic receptor antagonist on erectile dysfunction in streptozotocin-induced diabetic rats. J Urol. 2017; 107: 271.e1-271.e7. [CrossRef]

[9] Ozturk B, Gur S, Coskun M, Kosan M, Erdurak CS, Hafez G, Gonulalan U, Cetinkaya M. A new relaxant on human corpus cavernosum: Ferulago syriaca root extract. Afr J Pharm Pharmacol. 2012; 6(37): 2652-2656. [CrossRef]

[10] Garud MS, Kulkarni YA. Attenuation of renal damage in type I diabetic rats by umbelliferone-a coumarin derivative. Pharmacol Rep. 2017; 69(6): 1263-1269. [CrossRef] 
[11] Ramu R, Shirahatti PS, Swamy NS, Zameer F, Dhananjaya BL, Prasad NMN. Assessment of in vivo antidiabetic properties of umbelliferone and lupeol constituents of banana (Musa sp. var. nanjangud rasa bale) flower in hyperglycaemic rodent model. PLoS One. 2016; 11(3): e0151135. [CrossRef]

[12] Gao D, Zhang Yl,, Xu P, Lin Y, Yang F, Liu J, Zhu H, Xia Z. In vitro evaluation of dual agonists for PPARgamma/beta from the flower of Edgeworthia gardneri (wall.) Meisn J Ethnopharmacol. 2015; 162: 14-19. [CrossRef]

[13] Cengiz T, Kaya E, Oral DY, Ozakca I, Bayatli N, Karabay AZ, Ensari TA, Karahan T, Yilmaz E, Gur S. Intracavernous injection of human umbilical cord blood mononuclear cells improves erectile dysfunction in streptozotocin-induced diabetic rats. J Sex Med. 2017; 14(1): 50-58. [CrossRef]

[14] Yilmaz D, Bayatli N, Un O, Kadowitz PJ, Sikka SC, Gur S. The effect of intracavernosal avanafil, a newer phosphodiesterase-5 inhibitor, on neonatal type 2 diabetic rats with erectile dysfunction. J Urol. 2014; 83(2): 508 e712. [CrossRef]

This is an open access article which is publicly available on our journal's website under Institutional Repository at http://dspace.marmara.edu.tr. 